Journal of Business Research, Volume 88, July 2018, Pages 79-90

DOI: $10.1016 /$ j.jbusres.2018.03.009

\title{
Sensemaking, Sensegiving and Absorptive Capacity in Complex Procurements
}

\author{
* Daniel D Prior, \\ School of Management \\ Cranfield University, Bedford, MK43 0AL \\ United Kingdom \\ E-mail: daniel.prior@cranfield.ac.uk \\ Joona Keränen, \\ Lappeenranta University of Technology \\ School of Business and Management \\ P.O. Box 20, 53851 Lappeenranta, Finland \\ E-mail: joona.keranen@lut.fi \\ Sami Koskela, \\ Lappeenranta University of Technology \\ School of Business and Management \\ P.O. Box 20, 53851 Lappeenranta, Finland \\ E-mail: sami.koskela@,lut.fi
}

\begin{abstract}
Acknowledgments
The research was conducted in the RIVIS (Realizing Intangible Value from Integrated Solutions)-project funded by the Finnish Funding Agency for Technology and Innovation. The authors would like to thank Paavo Ritala, Asta Salmi, Robyn Prior, Sue Williamson and the anonymous reviews for their thoughtful suggestions that have helped improve the final manuscript.
\end{abstract}

January 2018 


\title{
Sensemaking, Sensegiving and Absorptive Capacity in Complex Procurements
}

\begin{abstract}
This study explores and describes i) the nature of knowledge exchange processes at the frontline employee (FLE) level and ii) how FLE sensemaking processes affect buyer firm knowledge management practices in complex procurement contexts. The study utilizes an indepth case analysis in the mining industry to identify a taxonomy of four buyer sensemaking investment/ supplier collaboration profiles, to describe three sensegiving supplier roles ('confidence builders', 'competent collaborators', and 'problem-solvers') and to explore how these evolve during complex procurement implementation. The study concludes with a conceptual model of the apparent linkages between sensemaking, sensegiving and buyer firm absorptive capacity in complex procurements. This study shows how micro-level (FLE) interactions influence macro-level knowledge integration (absorptive capacity) in the buyer firm. For managers, the study shows how the allocation of time and resources affects FLElevel knowledge exchange, with ultimate effect on buyer firm absorptive capacity.
\end{abstract}

Keywords: $\quad$ B2B, Knowledge Management; Solutions; Knowledge Intensive Business; Case Study; Supplier Relationships 


\section{Sensemaking, Sensegiving and Absorptive Capacity in Complex Procurements}

\section{Introduction}

Complex procurements involve the acquisition and integration of technically sophisticated products and services (Brown and Jones, 1998; Chen, Law, and Yang, 2009). Common in industries such as mining, construction, manufacturing, information technology and infrastructure, the buyer firm generally seeks overall improvements in their capabilities from complex procurements (Brady, Davies, and Gann, 2005; Flowers, 2004, 2007). Many of these outcomes rely on interactions between highly skilled frontline employees (FLEs) acting on behalf of exchange partners. These interactions aid in knowledge transmission and creation and, ultimately, produce the innovations, the creativity and the adaptability necessary to ensure successful outcomes (Andersen, Kragh, and Lettl, 2013; Levin, Thaichon, and Quach, 2016). In many cases, however, knowledge exchange processes are either unsuccessful or only partially successful (Reich, 2007; Shore, 2008). The persistence of these outcomes has led to speculation as to the causes of ineffective knowledge exchange in complex procurements (Reich, 2007; Shore, 2008).

Previous studies suggest that FLEs are more likely to share knowledge if they have sufficient motivation, skills and experience (Cadwallader, Jarvis, Bitner, and Ostrom, 2010; Wang, Wang, Long, Hou, and Ching, 2015). However, it is necessary for the behaviors of FLEs on both sides of the buyer-supplier dyad to complement each another (Brach, Walsh, Hennig-Thurau, and Groth, 2015). This can be difficult if FLEs have strong psychological associations with their own firms (Korschun, 2015), and if the culture of the firm is not conducive to knowledge sharing (Grabher, 2004). Complementarity is also important at the inter-firm level. Resource and systems compatibilities are necessary for productive inter-firm knowledge exchange (Ho and Ganesan, 2013; Vanpoucke, Vereecke, and Boyer, 2014; Vargo, Maglio, and Akaka, 2008). Despite acknowledgement that both micro and macro level 
dynamics are important, few studies consider the interactions between these levels of analysis, particularly for complex procurement scenarios (Lewin, Massini, and Peeters, 2011; Mattsson, Corsaro, and Ramos, 2015; Robertson, Scarbrough, Swan, and Scarbrough, 2003). The central purpose of this study is to understand how FLE cognition affects taskrelated learning in complex procurement contexts and, as such, the study responds to calls for research in this area (Henneberg, Naudé, and Mouzas, 2010; Mattsson et al., 2015). The findings begin with a taxonomy of FLE profiles according to buyer firm sensemaking investment (i.e. allocations of time, effort and resources towards interpreting supplier information) and supplier collaboration approach. In this, we argue that complexity affects sensemaking activities relative to the degree of buyer-supplier engagement at the dyadic level. These findings extend the view that social integration mechanisms allow development of shared meanings (Peters, Pressey, and Johnston, 2016) by identifying two sorts of 'levers' available to partner firms - buyer sensemaking investments and supplier collaboration approach - and by describing the implications of four different combinations of these mechanisms.

Earlier studies suggest that networks are formed by the views of the involved actors (Ellis and Hopkinson, 2010; Gadde, Huemer, and Håkansson, 2003; Leek and Mason, 2010). Despite this, the roles of actors as sensegivers in this process receives little attention. Our next set of findings reveal three sensegiving roles that supplier firm representatives adopt during complex procurements: confidence-builders, competent collaborators, and problemsolvers. This finding supports a theorization about the effects of value creation roles with specific reference to task-relevant knowledge creation and transfer and builds on earlier studies that demonstrate the importance of actors' perceptions of network roles when understanding network dynamics (Abrahamsen, Henneberg, and Naudé, 2012). By focusing on the sensegiving roles of supplier representatives, the study partially addresses current 
concerns in the service logic literature about the clarity of roles in value co-creation processes (Grönroos, 2008; Grönroos and Voima, 2013).

The final set of our findings map how complex procurement implementation stage affects the interplay between buyer FLE sensemaking and supplier representative sensegiving. While several studies suggest sensemaking is important for individuals when interpreting network change (Colville and Pye, 2010; Corsaro, Ramos, Henneberg, and Naudé, 2011; Leek and Mason, 2010), the effects of this process at the dyadic level are less clear. It appears that current views assume a situated notion of sensemaking in that actors have relatively stable identity profiles in dynamic situations (Weick, Sutcliffe, and Obstfeld, 2005) and that this helps them understand 'why' and 'how' networks shift (Abrahamsen et al., 2012). While this may be true, our findings suggest that role prominence differs depending on the task requirements of complex procurement implementation stage. This is consistent with changes in network position (Leek and Mason, 2010), yet ours is the first study to link this process to a specific implementation process. In uncovering this view, we develop a dynamic notion of absorptive capacity that illustrates the interplay between micro and macro levels of analysis.

The outcomes of this study highlight the importance of FLEs in supplier knowledge management practices during complex procurements. The findings draw on an in-depth case analysis of a complex procurement in the mining industry ${ }^{1}$ and, as such, they are most relevant to FLEs and managers operating in similar contexts. For managers in buyer firms, it is clear that buyer sensemaking investments affect the absorptive capacity of the buyer firm as a whole. By not supporting sensemaking activities, the effects of complexity become acute. This is likely to produce organizational paralysis through perceptions of high task

\footnotetext{
${ }^{1}$ Our case centers on the design, delivery, implementation, and maintenance of a combination of units for dewatering plants. Dewatering is a part of the value chain from ore to metal, and it is focused on separating solid and liquid materials to optimize the processes in mineral slurry dewatering, process water reuse and by-product handling in metals and chemical processing as well as in industrial water treatment.
} 
diversity, information asymmetry and environmental dynamism. Excessive sensemaking investments, on the other hand, are also counterproductive since this produces slack while also encouraging supplier opportunism (i.e. they may take advantage of the situation). From a supplier firm's perspective, the recognition that supplier firm representatives adopt different sensemaking roles, and that these contribute to different relational dynamics according to implementation stage, should allow a clearer set of decision-making cues when determining collaboration approach.

\section{Literature Review}

\subsection{Sensemaking and Sensegiving in Business-to-Business Interactions}

As the primary interfaces between the firm and its environment, FLEs have two important roles. First, they are gatekeepers that determine what information to allow entry to the firm from external sources (Cohen and Levinthal, 1990; Lewin et al., 2011). Second, FLEs also determine the format in which information enters the firm. Supply chain studies generally support the notion that FLEs act as the social mechanisms that interact with members of the firm's supplier network (Preston, Chen, Swink, and Meade, 2016; Stolze, Murfield, and Esper, 2015), with these interactions often supporting knowledge exchange processes (Liao and Marsillac, 2015; Stolze et al., 2015). Many studies adhere to the notion that this involves sensemaking, or the “... ongoing retrospective development of plausible images that rationalize what people are doing" (Weick et al., 2005, p. 409). As such, the nature of the knowledge exchange process rests with individuals. To date, however, there has been limited investigation of the process dynamics that underpin the interactions between specific individuals (such as FLEs) and the implications of these at the firm level (Henneberg et al., 2010; Mattsson et al., 2015).

When understanding sensemaking in business-to-business interactions, many studies focus on network pictures. This involves an actor interpreting their business environment 
through a set of subjective cues (Colville and Pye, 2010; Geiger and Finch, 2010; Holmen, Aune, and Pedersen, 2013). Importantly, network pictures help actors to simplify complex phenomena through information categorization and the application of a set of heuristics. Recent studies show that network pictures are useful when understanding key supplier relationships. Holmen et al. (2013) identify the importance of network picture complementarity across the buyer-supplier dyad. They show that the network pictures held by each exchange partner are subject to change, and that the impetus for this largely depends on how systematic or focused buyer FLEs are when pursuing new opportunities. Leek and Mason (2010) also consider the application of network pictures at the dyadic level. They show that the dimensions of network pictures largely relate to the boundaries of each network picture, the frequency of communication, and the perceptions of network atmosphere vary systematically with employee managerial level and function.

Much of the current literature focuses on sensemaking as this affects actors within buyer firms or networks more broadly. However, there are also situations where actors may want to create alternative perceptions in the minds of other actors. In this case, they engage in sensegiving - where they attempt to persuade others about the merits of an alternative viewpoint or interpretation (Gioia and Chittipeddi, 1991; Hill and Levenhagen, 1995; Maitlis and Lawrence, 2007). To this end, managers often engage in a deliberate narrative that often involves storytelling, the use of metaphors and/ or through the routinization of different practices (Fiss and Zajac, 2006; Hong, Snell, and Mak, 2016; Monin, Noorderhaven, Vaara, and Kroon, 2013). It is for these reasons that sensegiving is often closely associated with organizational change. In the relatively few studies that consider sensegiving in business-tobusiness exchange, coopetition is the primary subject matter. Studies in this area show that sensegiving is important when senior and middle managers attempt to reconcile with the 
identities of competitors and cooperators and that this affects relational dynamics (LundgrenHenriksson and Kock, 2016; Tidström and Rajala, 2016).

In this study, we conceptualize FLE-level knowledge exchange in complex procurement interaction processes as an interplay between the sensemaking endeavors of buyer firm FLEs and the sensegiving efforts of FLEs from buyer firms. In this, we focus on the practices of specific actors in their efforts to develop shared cognitions as these relate to task completion rather than network pictures in a general sense (Mouzas and Henneberg, 2015; Peters et al., 2016). Earlier studies show that complex procurement implementations are technically and socially complex enterprises that involve temporary organizational structures (Burke and Morley, 2016; Neely, 2014; Söderlund, Hobbs, and Ahola, 2014; Töllner, Blut, and Holzmüller, 2011). This context requires dynamic FLE engagement, often to complete knowledge-intensive task requirements (Aarikka-Stenroos and Jaakkola, 2012; Haas, 2006; Santos-Vijande, López-Sánchez, and Rudd, 2016). This suggest that this is a relatively unique context that provides a novel interpretative lens.

\subsection{Absorptive Capacity in Complex Procurements}

Absorptive capacity, as the ability for the firm to deploy resources to undertake acquisition, assimilation, transformation and exploitation of knowledge (Zahara and George, 2002), has often been associated with superior competitive outcomes at the firm level. With high absorptive capacity, the firm is able to develop robust and unique knowledge resources that support innovation and operational performance outcomes (Ali, Seny Kan, and Sarstedt, 2016; Murovec and Prodan, 2009). Accordingly, new product launches, licenses and patents are downstream outcomes of absorptive capacity (Cohen and Levinthal, 1989, 1990; Todorova and Durisin, 2007; Zahara and George, 2002). An alternative view is also apparent. Studies of high technology implementation processes suggest that absorptive capacity relates to the ability to engage with a partner firm across the dyad (Zaheer, Hernandez, and Banerjee, 
2010). Relatively few studies of this notion of absorptive capacity exist. Instead, studies tend to focus on related concepts such as resource and systems integration, knowledge sharing routines and knowledge-sharing mechanisms (Dyer and Singh, 1998; Ho and Ganesan, 2013; Nagati and Rebolledo, 2012).

Given the focus of this study, our notion of absorptive capacity relates more to the ability of partner firms to recognize valuable information, to exchange it, and to integrate it for commercial outcomes (Zaheer et al., 2010). The commercial outcomes of central interest relate primarily to complex procurement implementation. It seems that the task-related focus of knowledge exchange efforts at the FLE level will not necessarily result in an ongoing, organic contribution to firm-level dynamic capabilities. The fragmented nature of knowledge exchanges is likely to harbor multiple viewpoints and capabilities in FLEs (Grabher, 2004; Hoegl and Gemuenden, 2001; Turner and Müller, 2003). This has the potential to yield significant differences in the interpretation of phenomena. While there is some evidence to indicate a group consensus will eventually arise, it seems that this will not always be the case due to the heterogeneity of stakeholder viewpoints and the complexity of the procurement (Reiman, Shen, and Kaufmann, 2016; Roseira, Brito, and Ford, 2013; Tangpong, Hung, and Ro, 2010). Third, the knowledge-intensive context characterizing complex procurements is likely to demand adaptability and flexibility from FLEs. Previous studies highlight the uncertainty and ambiguity of complex procurements, with several studies also suggesting these environments require extensive problem-solving and customization behaviors (AarikkaStenroos and Jaakkola, 2012; Coelho and Augusto, 2010; Waller, 1999).

Earlier absorptive capacity theory suggests that firms rely heavily on individual employees to recognize and integrate valuable knowledge (Cohen and Levinthal, 1989, 1990; Lewin et al., 2011; Todorova and Durisin, 2007; Zahara and George, 2002). The opportunities for FLE-level knowledge exchange processes to contribute to the absorptive 
capacity of the firm depend on the constraints and enablers that shape this process. As Tourish and Robson (2006) suggest, these constraints likely shape the upward communications of FLEs. Previous studies show that the nature of complex procurement implementation requires time and context-specific matches between actors (Grabher, 2004; Lindner and Wald, 2011). The propensity for knowledge exchange, therefore, rests with these interactions. To date, however, there has been little consideration in the extant literature of these phenomena.

\section{Methodology}

\subsection{Research Design}

To address the goals of the study, we adopted a research design that centers on theory development. Hence, we conducted a three-year case analysis of a large, Finnish mining company with global operations. A single case research design aims at understanding phenomena in detail and providing rich descriptions (Dubois and Gadde, 2014, 2002; Yin, 2009). Given this, the outcomes of our study are most relevant to complex procurement contexts. These are more likely to resemble substantial attempts for buyer firms to improve their underlying capital base. Complex procurements generally involve upgrades to plant and equipment of some kind, with these being more common in industries such as mining, construction, manufacturing, information technology and infrastructure (Biggemann, Kowalkowski, Maley, and Brege, 2013; Brady et al., 2005; Flowers, 2004, 2007). Given the nuances of these contexts, we felt that they would provide some interesting opportunities to examine complex procurements and FLE knowledge exchanges specifically.

We initially used a theoretical sampling approach to identify the respondent firm. Since we were interested in complex procurements, we looked for examples of these. Our search focused on the four common elements identified in the literature that defines these phenomena: i) high cost/ high risk, ii) interactions between multiple stakeholders at multiple 
levels, iii) long time horizons ( $>12$ months), and iv) technically complex products and services (Biggemann et al., 2013; Brady et al., 2005; Flowers, 2004, 2007). This narrowed the basis of our search activities to capital goods industries. The research team approached several companies that we considered likely to engage productively in a long-term research project. This then led to endorsement from the company in which we conducted the study. At the time of writing, this company had operations spanning every continent, a 150 -year history, 4,200 personnel and more than $€ 1.05$ billion in annual turnover.

To streamline the management of the study, we focused on the operations of a single division within the company ${ }^{2}$. This allowed us to concentrate on FLEs with direct involvement in complex procurement implementation processes. Since the Finnish mining company was the supplier firm in these situations, we also engaged members of buyer firms throughout the process, which we detail in the sections below. Our analytical process has similarities with an applied business ethnography since we draw on our subjective interpretations of qualitative data to describe the behaviors of FLEs in social settings by analyzing their communicative practices (Atkinson and Hammersley, 1995; Fetterman, 2010; Kalou and Sadler-Smith, 2015). Ethnography has become a popular means to understand phenomena in business markets (Pressey, Gilchrist, and Lenney, 2014). Consistent with both single case methods and ethnography, we combine interview data, field notes of meeting observations and content analyses of key documents to induce and triangulate our findings (Atkinson and Hammersley, 1995; Fetterman, 2010; Yin, 2009).

\subsection{Research Process}

Our research process began in June 2013 and concluded in February 2016. This involved three distinctive, yet partially overlapping phases that lasted between eight and twelve months each. This included i) defining the research agenda and selecting respondent

\footnotetext{
${ }^{2}$ As stated in the introduction, we focused on dewatering solutions implementations.
} 
customers, ii) designing and conducting the primary field work, and iii) analyzing, revising, and validating the results. The second and third authors were embedded in the research context for this period. At the time of commencement, the second author had about two years of experience in research collaboration with the Finnish mining company while the third author had been a part-time employee with this firm for about five years. This provided the research team with an extensive pre-understanding of mining operations and processes, the technical requirements of the dewatering solution and its lifecycle, and the operational and political landscape at customer locations, as well as access to key decision makers. These authors actively participated in meetings, conversations and observations at locations where dewatering plant solution design and implementation processes took place. While this provided access to rich data, it also involved direct engagement in the empirical context. As such, the findings of the study rest on a dialectic between subjective interpretation and objective appraisal, which is a positive attribute of single case, ethnographic research (Atkinson and Hammersley, 1995; Fetterman, 2010; Yin, 2009).

\subsubsection{Interviews}

During the fieldwork phase, we conducted semi-structured interviews with 22 key decision-makers. Sales managers from the Finnish mining company identified participants, which we then contacted (a list of interview respondents appears in Table 1). Target respondents were senior decision makers with significant experience in procuring dewatering plant solutions or similar systems. The purpose of the interviews was to establish the nature of supplier management practices. Key topics of interest included how they participate in the purchase process, what they seek from suppliers, how they enable suppliers to fulfill their tasks and how culture influences these behaviors (a list of interview questions appears in Appendix A). The duration of interviews was between 24 and 64 minutes, with interviews 
recorded and subsequently transcribed verbatim. This resulted in 355 pages of interview transcripts.

-Insert Table 1 About Here-

\subsubsection{Meetings}

During the course of the study, authors two and three participated in and observed 21 meetings, of which there were four main types. Sales meetings included an introduction of the local operations, and a negotiation between a sales team from the Finnish mining company, and up to four senior decision makers from the customer firm (seven meetings). This provided an opportunity to observe behaviors in a real-life social setting. Steering group meetings with the Finnish mining company provided opportunities to interact with senior managers with interest in the project (four meetings). These meetings also allowed us to refine project parameters such as respondent selection and timetable planning. They also allowed us to elicit feedback and alternative interpretations in relation to the emergent results. Project team meetings comprising representatives from the Finnish mining company and the research team allowed us to develop and refine our understanding of key concepts (seven meetings). We also presented the key findings of the study as they emerged to a broader managerial audience, including key members from both the steering group and the project teams (three meetings). These presentations allowed us to confirm our findings by exposing tentative findings and then establishing consensus through dialogue with meeting attendees (Lincoln and Guba, 1985). During the course of meetings, we took meeting notes (about 100 pages) and obtained presentation slides and other documents (which totaled more than 100 pages).

\subsubsection{Document Analysis}


We also analyzed a wide range of supplementary documentation. This allowed us to explore the contextual influences relating to the mining industry while also gaining greater depth of understanding in customer and supplier firm dynamics. We considered two industry reports and a customer study to uncover industry trends as these relate to dewatering plant solutions. We also had access to customer and supplier annual reports, sales and marketing materials, technical reports and descriptions of key processes, including product life cycles. A range of confidential documents from the Finnish mining company supplemented these publicly available sources. Confidential documents included a strategic positioning analysis report, customer case histories, customer surveys, internal customer reports, internal newsletters and market analyses. When combining all documents, they totaled more than 600 pages of content.

\subsection{Data Analysis}

An abductive process was used to analyze and interpret the empirical materials produced during the fieldwork (van Maanen, Sørensen, and Mitchell, 2007). Specifically, we employed systematic combining which involves an iterative comparison between findings in the data and the existing literature in the field (Dubois and Gadde, 2014, 2002). This approach was initially designed for single case study contexts as a means to build new theoretical interpretations of emergent concepts. Central to this procedure is the notion of 'matching', which involves mapping theoretical concepts that already exist and then overlaying them with the emerging findings. Where differences exist, this leads to the identification of new theoretical ideas. Consequently, the study involves four sets of findings that relate to the initial two research goals. We explain them, and the accompanying analytical processes we employ, in the sections below.

\subsection{Data Credibility}


We used Lincoln and Guba's (1985) approach to establish the credibility of the findings. We first established the face validity of our findings. This involved a number of steps. First, we ensured that interview respondents had sufficient familiarity with complex procurements. Hence, our initial interview questions probed the respondent's background to establish their level of experience. Second, the meeting observations all focused on some aspect of dewatering solutions implementation. This meant that attendees all were conversant with relevant implementation issues. Third, the document analyses we conducted all related to dewatering solutions implementation. Between these measures, we felt that sufficient face validity existed across our data sources.

We next focused on establishing reliability. We took three steps in this process. First, we triangulated findings across multiple data sources, ensuring we had at least three pieces of data from different sources to support each of the aspects of our findings (Yin, 2009). Next, we conducted independent co-analyses (Miles and Huberman, 1994), which involved independent appraisals of the datasets given the agreed goals of the study. This produced a moderate level of consensus after an initial process, with two further iterations then improving inter-rater reliability to $80 \%$ across the three data coding processes (James, Demaree, and Wolf, 1984; Tinsley and Weiss, 1975). Lastly, we exposed a broad managerial audience with familiarity of the mining industry to our findings during ten meetings (see our process description on this in the previous section). This allowed us to establish a consensus of findings through dialogue (Lincoln and Guba, 1985).

\section{Findings}

The findings from the study appear in three sections. The first section develops a taxonomy that categorizes supplier collaboration according to the degree of investment the buyer firm makes in sensemaking activities. The second section describes three main supplier sensegiving roles that emerge from the data. The third section maps the relative importance 
of supplier sensegiving roles in terms of implementation stage and the types of supplier collaboration that emerge in the first findings section.

\subsection{Towards a Taxonomy of Supplier Collaboration Given Sensemaking Investment}

We begin our analysis by examining the relative interplay between sensemaking of buyer firm FLEs and the sensegiving actvities of their supplier firm counterparts. Our analyses center on the narratives about FLE expectations of their task requirements, the associated knowledge exchange process and the respective roles of both themselves and the primary FLEs they interact with from their counterpart firm (i.e. the buyer or supplier firm). Narrative analysis focuses on the stories or metaphors that respondents use to explain a phenomenon of interest (Cayla and Arnould, 2013; Grayson, 2007; Mäläskä, Saraniemi, and Tähtinen, 2011), and, as such, is consistent with the precepts of sensemaking and sensegiving (Weick, 1995; Weick et al., 2005). With these parameters in place, we interrogated the dataset for appropriate stories and metaphors, which we categorized as most relevant to buyer firm FLE sensemaking or supplier firm FLE sensegiving respectively using NVivo software. Using these two pools, we began with an open coding process to identify major themes and a selective coding to identify specific attributes (Lincoln and Guba, 1985; Miles and Huberman, 1994). Table 2 contains a descriptions of the outcomes of this process.

When considering buyer firm FLE sensemaking activites, we were mindful that previous studies identify important sensemaking attributes such as enactment, retrospection, plausibility, routinization, and retention (Vlaar, Van den Bosch, and Volberda, 2006; Weick et al., 2005). So, we searched for evidence of these actvities. We identified previous studies on assessing information value and information/ knowledge processing (see Table 2 for indiciative sources). These studies overwhelmingly concentrate on the inter-firm level rather than on FLE interactions and do not consider complex procurement situations. Consequently, we adapted these concepts to our purpose. Important to our study is the notion of bounded 
reliability, whereby FLEs face resource constraints that curtail their ability to engage in all actvities simultaneously (Kano and Verbeke, 2015; Verbeke and Greidanus, 2009). This led to a search for evidence that FLEs make deliberate decisions about time and other resource allocations. While several authors highlight the importance of micro-level resource management decisions (Cantù, Corsaro, and Snehota, 2012), we see this as an important element of buyer firm FLE sensemaking activites.

We next directed our attention to supplier firm FLE sensegiving actvities. While sensegiving is also not a new concept, it is less developed than sensemaking in the extant literature. We noted that sensegiving often involves attempts to influence others through storytelling, metaphors and narrative (see Table 2 for indicative citations). We see this is important when affecting organizational change (Fiss and Zajac, 2006; Gioia and Chittipeddi, 1991; Hill and Levenhagen, 1995; Monin et al., 2013), and, to less-studied extent, to interfirm interactions (Shepherd, Patzelt, and Wolfe, 2011). We also saw bearing new knowledge or information as an important aspect of sensegiving, with this being more common in selling situations and when conveying product information (Ballantyne, Frow, Varey, and Payne, 2011; Squire, Cousins, and Brown, 2009). However, these concepts had not previously been adapted to accommodate an FLE interaction in complex procurements. Our evidence indicates these concepts still have relevance in our setting, albeit for specific task-related applications. As with buyer firm FLE sensemaking activites, we consider supplier firm FLE sensegiving actvities subject to bounded reliability. This also leads us to conclude that resource allocations have the same importance in this respect. In sum, we see supplier firm FLE sensegiving actvities as efforts towards supplier collaboration for task completion and that this is, in large part, an information conveying effort. 
-Insert Table 2 About Here-

Our analyses then involved exploring the interplay between buyer firm FLE sensemaking and supplier collaboration approach. For this purpose, we searched for respondent narratives indicative of 'high' versus 'low' levels of engagement across both dimensions. For buyer firm FLE sensemaking, we searched for evidence of relative information appraisal, information processing and resource allocations towards tasks that involved engagement with suppliers. For supplier collaboration, we looked for evidence of influencing, knowledge bearing and resource allocation towards tasks that involved engagement with buyers. Through these analyses, we began to notice overlaps between buyer and supplier perspectives. We continued our search by triangulating between the narratives from both perspectives. This was a particularly crucial step since the narratives we found were based largely on subjective perception. Where we found a high level of agreement, these became the basis for further attempts to establish credibility. To understand the extent of this interplay, we used NVivo to map where there were high levels of agreement between multiple sources (Cayla and Arnould, 2013; Coviello and Joseph, 2012). We disregarded cases, where we did not achieve high confirmation between the multiple sources available or where there was insufficient evidence. This resulted in a taxonomy of four profiles (see Table 3).

Type I profiles involve low buyer investments in sensemaking and heavy reliance on suppliers for sensegiving. In these scenarios, the buyer firm often did not have sufficient resources to allocate to sensemaking efforts. This tends to indicate excessive demands for FLE time from multiple commitments and/ or managerial perceptions that a specific procurement is low risk. Hence, the buyer firm often places the onus on the supplier firm to 'take them through the process'. Type II profiles involve high sensemaking investments and 
high supplier collaboration. These generally reflect procurements that have high resourcing and that buyer firm managers perceive as important. This means they allocate appropriate personnel with high skills and experience relevant for the specific procurement and, as such, they are most likely to collaborate extensively with suppliers, but in a selective fashion, so as to address perceived gaps in capacity or knowledge.

Type III profiles involve low sensegiving investments and low supplier collaborations. Some of our data indicate somewhat adversarial relationships with suppliers. Consequently, buyer firms avoid utilizing supplier skills and experience. Instead, they prefer to keep activities 'in house'. These profiles also reflect the low priority and resourcing that buyer firm managers assign to these procurement tasks. Type IV profiles also involve low supplier collaboration efforts, with this again reflecting efforts to control procurement actvities internally. However, these instances do not necessarily reflect the low prioritization of the procurement. Instead, the buyer firm allocates internal resources with sufficient expertise and capacity to complete assigned tasks.

Each of the four profiles represent extreme cases. Many of the sensemaking investment/ supplier collaboration combinations we identified fall at a point in between the extremes. However, it is clear that supplier collaboration is often subject to buyer firm control. In this, we found two main dynamics. 'Pull'-based approaches to collaboration occur when buyer firms perceive suppliers have important expertise and capacity and, as such, they demand the services on offer. These services can involve allowing the supplier to guide them through an entire procurement process (Type I) or to guide them through specific aspects of a procurement process (Type II). 'Push'-based approaches to collaboration, however, involve suppliers actively pursuing opportunities to work with the buyer. This generally reflects more adversarial attitudes on the buyer's behalf. This involves utilizing suppliers only for specific 
tasks (Types III and IV). Given these observations, it appears that pull-based approaches to supplier collaboration are more likely to enable positive knowledge exchanges.

-Insert Table 3 About Here-

\subsection{Mapping Supplier Sensegiving Roles}

The next phase of analysis focused on supplier collaboration as sensegiving. For this, we draw on role theory, which involves assigning socially defined categories to the behaviors of supplier FLEs (Biddle, 1986). Current buyer-supplier interaction studies center on supplier roles, with most studies focusing on job designations such as sales managers or product managers (Agnihotri, Vieira, Senra, and Gabler, 2016; Goolsby, 1992; Lysonski and Johnson, 1983), or on expectations associated with roles (Bechky, 2006; Homburg, Wieseke, and Bornemann, 2009; Wieseke, Ahearne, Lam, and Dick, 2009). Current debates in service logic suggest that roles and tasks have ambiguous associations and that there is a need to establish greater clarity here (Grönroos, 2011; Grönroos and Voima, 2013). Consequently, our analysis focuses on how supplier firm FLEs create valuable outcomes for buyer firm FLEs, particularly as these relate to task completion.

Through our narrative analysis approach, we identified a range of stories and metaphors that described the key behaviors of supplier firm FLEs and their outcomes for buyer firm FLEs. Given the context of our dataset, we consistently observed dynamism and uncertainty. This led to multiple stories about the need to 'establish credibility', 'to justify actions' and to 'have legitimacy' so as to substantiate the required actions. The role of supplier FLEs was often to provide this since they were often 'outsiders' with 'expertise' (rather than partial employees, Mills and Morris, 1986; Santos-Vijande et al., 2016), which 
often allowed buyer firm FLEs to justify their actions to important stakeholders and/ or to achieve required task outcomes efficiently.

Drawing on the metaphors and stories we had identified through NVivo that indicate achieving legitimacy as the primary role of supplier FLEs, we next searched for a set of explicit behaviors and their outcomes from the buyer firm FLE perspective. By identifying outcomes, we then used these to categorize behaviors and to define behavioral roles (as opposed to positions within a hierarchy). We eliminated data that addressed more than one category. We also triangulated our findings through iterative comparisons across multiple data sources. This led us to define three major supplier FLE sensegiving roles.

Confidence-builders attempt to reduce perceived risk through the endorsement of buyer firm FLE actions. Similar to the use of celebrities or the invocation of senior managers' wishes, confidence-building utilizes reflected legitimacy to substantiate actions (Hung, 2014; Liu, Huang, Luo, and Zhao, 2012). Competent collaborators simplify information about context, the nature of problems and/ or they directly engage in task completion. Through their efforts, they reduce perceived task complexity and/ or uncertainty. Previous studies identify these roles as important to implementing corporate change, although there has been little consideration of these as important in complex procurements. Lastly, problem-solvers were active in identifying, describing and/ or enacting courses of action that address implementation problems. While previous studies highlight problem-solving as an important type of action, we see it as also part of a role mandate. Table 4 contains a summary of these roles.

Since each of these roles legitimize buyer firm FLE behaviors in some way, we see them as inter-connected (as we suggest in Figure 1). While our narrative analysis suggests one role may dominate more than others, this often depends on the individual FLE and the implementation context. 
-Insert Table 4 About Here-

-Insert Figure 1 About Here-

\subsection{Supplier Sensegiving According to Implementation Stage}

The findings also suggest that the relative importance of supplier sensegiving roles is dynamic. Complex procurements often involve lengthy implementation schedules (Brady et al., 2005; Töllner, Blut, and Holzmüller, 2011; Tuli, Kohli, and Bharadwaj, 2007). The findings appear to support the notion that different supplier sensegiving roles differ in their importance according to implementation stage. To ascertain the implications of this, we reflected on the taxonomy of sensemaking/ sensegiving we describe in section 4.1. We intentionally adopted a simplistic notion of procurement implementation processes as consisting of 'pre-sales', 'implementation' and 'post-implementation' since this would allow a simple way to identify important milestones and is broadly consistent with the approaches adopted in earlier studies (Abrahamsen et al., 2012; Gioia and Chittipeddi, 1991; Monin et al., 2013). Our next step involved a cross-mapping between each of the profiles in the taxonomy against evidence of implementation stage (Coviello and Joseph, 2012). We then cross-checked and triangulated findings. Table 5 contains a summary of these findings.

Type I profiles tended to value confidence-building at the pre-sales stage since this helped build support for engaging a supplier capable of taking a leading role in the implementation process. Problem-solving then became more important during implementation and post-implementation. These sensegiving roles tended to focus on addressing specific concerns of buyer firm FLEs while also adapting to the nuances associated with integrating complex systems with existing buyer firm infrastructure. Type II profiles sought competent collaborators during the pre-sales stage. This allowed the precise 
formulation of implementation plans and design specifications. These then enabled suppliers to focus on specific, complex activities. This meant that problem-solving was also important in the subsequent stages of implementation and post-implementation. These tended to focus on in-depth collaborations regarding the specific aspects in which the supplier was involved.

Type III profiles also valued competent collaboration sensegiving roles at the presales stage. This generally involved an expectation that suppliers would assemble a 'solution' by presenting a proposal that integrates multiple products and services in a manner that preemptively addresses the idiosyncrasies characterizing the buyer firm. In this, suppliers could demonstrate sufficient knowledge and skills that would make them appropriate collaborators. Problem-solving became more important during implementation and postimplementation stages, where these activities focus more on integrating their proposed solutions with existing supplier systems and by troubleshooting. Type IV profiles sought confidence building in the pre-sales stage. Significant investments in due diligence activities were likely as means to ensure buyer firms had sufficient information to understand suppliers. If suppliers could 'pass the test', this would increase buyer firm confidence. During implementation, problem-solving became more important. This normally meant frequent yet precise communications about emergent issues and the implementation of their specific task responsibilities. Since buyers often were confident in their own skills and resources, the postimplementation stage saw higher emphasis on providing resources to address specific issues. Hence, buyer firms sought confidence building in the form of warranties and assurances of help if necessary.

-Insert Table 5 About Here-

\section{Discussion}


The findings suggest that the sensemaking and sensegiving processes between FLEs are important considerations in complex procurements. The buyer sensemaking investment approach determines i) how much information an FLE is exposed to and ii) how they appraise that information. While earlier studies suggest that upward dialogue (Nonis, Sager, and Kumar, 1996; Tourish and Robson, 2006) can translate FLE-level information to firmlevel outcomes, the present study suggests that buyer sensemaking investments influence this process by shaping information flow. The determinants of information flow and form likely involve a discursive relationship with norms at the firm level, where these norms help to determine the relative value of information. Hence, this becomes one emphasis of an intersubjective consensus (Martinsuo and Ahola, 2010; Squire et al., 2009). The norms against which these judgements form relate to task specificities rather than broader forms of knowledge. This is largely due to the temporal nature of FLE work in complex procurements. Given this, it is more likely that buyer firm absorptive capacity will center on generating efficient outcomes at the task level. It is also likely that the nature of broader learning endeavors of the kind likely to produce innovative new outputs, occurs at the firm or network levels instead (Choi, Kim, and Lee, 2010; Nätti, Hurmelinna-Laukkanen, and Johnston, 2014).

The study also shows how supplier FLE sensegiving approach affects their ability to engage. The study does this by profiling how buyer FLE sensemaking and supplier FLE sensegiving interact. The resulting taxonomy illustrates the various narratives that underpin engagement approach. This is the first attempt to profile these interactions in complex procurements. Indeed, related studies describe dyadic knowledge flows in a broad sense (e.g. through value creation as a buyer-supplier interaction (Aarikka-Stenroos and Jaakkola, 2012; Hilton, Hughes, and Chalcraft, 2012) without considering the possibility for variances in FLE 
engagement approaches. The more nuanced view that this study suggests could help provide greater clarity as to the micro-level knowledge sharing dynamics of FLEs.

The study also identifies 'legitimizing' is an underlying driver of these engagements, with these ultimately resulting in three main supplier FLE sensegiving roles (confidence building, competent collaboration and problem-solving). Several studies question the nature of buyer versus supplier roles in value co-creation (Grönroos, 2008, 2011; Grönroos and Voima, 2013). The findings in the present study identify an over-arching motivation that is relevant to knowledge intensive businesses (Aarikka-Stenroos and Jaakkola, 2012; Haas, 2006; Santos and Spring, 2015). The gradation of legitimizing roles into three primary forms yields greater clarity as to how legitimizing manifests as role behaviors. This contrasts with earlier studies that focus either on legitimate roles associated with organizational positions (such as sales managers) or on behaviors such as problem-solving and adaption that are not role specific. The present study suggests that goal-oriented behaviors influence the nature and form of value co-creation roles. As such, these insights shift the emphasis of value cocreation roles to goal-oriented behaviors of specific actors and that these involve sensegiving endeavors.

While sensemaking is dynamic, reflexive and emergent, the present study illustrates how this relates to complex procurement. Previous studies illustrate this in terms of network picture evolution and network position (Colville and Pye, 2010; Leek and Mason, 2010). However, there has been less consideration of an emergent collaborative process at the dyadic level, with current studies either focusing on the composition or complementarity of partner network pictures (Holmen et al., 2013; Leek and Mason, 2010). Our study shows that implementation stage affects role prominence and that this differs depending on sensemaking/ sensegiving profile. This fine-grained understanding shows that supplier FLEs emphasize different sensegiving roles during implementation and that sensemaking/ 
sensegiving profiles affect their relevance. Ultimately, this emergent process affects the buyer firm's ability to integrate and exploit information by shaping its availability and its format. Figure 2 is a graphical representation of the links between sensemaking, sensegiving and absorptive capacity in complex procurements.

-Insert Figure 2 About Here-

\subsection{Managerial Implications}

For managers in complex procurements, the study highlights micro-level processes that affect buyer firm absorptive capacity. For buyer firm managers with implementationrelated designations, optimizing FLE sensemaking is a question worth pondering. An important observation in this regard is that FLEs face time and resource constraints, so ensuring these are sufficient for the task at hand will increase the probability that an 'ideal' sensemaking opportunity exists for the FLE. Managerial beliefs about what this comprises are likely to relate to i) their expectations of supplier firm FLE sensegiving endeavors, ii) their ability to allocate resources, and iii) the relative importance of assigned tasks to the FLE. Differences between managerial beliefs and those of FLEs are likely to create tensions. Where an FLE believes in the importance of the sensegiving activity at hand, and their manager does not, this can give rise to situations where managers require a delicate and nuanced approach to managing FLE expectations. The decisions taken in these respects have important implications of buyer firm absorptive capacity. This is because they screen information flows and this ultimately determines the scope for knowledge integration and exploitation.

Encouraging fruitful FLE interactions across the buyer-supplier dyad is also a challenge worthy of consideration. While this study has produced a series of profile and role 
descriptions of sensemaking and sensegiving in complex procurements, it has not addressed what would make these 'fruitful'. Ultimately, this will depend on the nature of the task at hand, its urgency and its relative importance. An understanding of the likely dynamics to emerge can then be overlaid with the findings in the study to help identify the likely i) buyer firm FLE sensemaking approach, ii) supplier firm FLE sensegiving approach, iii) how these converge as interactions, and iv) how these evolve. This could help inform project planning by anticipating likely FLE knowledge management challenges and associating these with buyer firm absorptive capacity.

\subsection{Limitations and Future Research}

The purpose of this study was to develop new theoretical insights as they relate to sensemaking, sensegiving and absorptive capacity in complex procurements. Given this, the outcomes of the study are descriptive and exploratory. The findings also relate to an in-depth case study of a large Finnish mining company. While this empirical process is suitable given the goals of the study, it is relatively unique. Capital goods procurement contexts are the most closely related. Hence, the findings of the study do not necessarily generalize beyond these contexts. This gives rise to a need for further research to generalize the findings of the study to other empirical settings. Moreover, the need to understand the nature of sensemaking and sensegiving at the FLE level is a topic in need of further research attention, particularly in supply chain studies. When studying contexts with high service components, the need for customization, and adaptability, the role of FLEs is very important. As the gatekeepers to both buyer and supplier firms, FLEs have the potential to dramatically alter the ability for both firms to capture and capitalize on external knowledge. Hence, these are topics in need of further research attention in supply chain contexts.

\section{Conclusion}


We develop a taxonomy containing four buyer sensemaking investment/ supplier collaboration profiles that categorizes the likely combinations of sensegiving and sensemaking activities of FLEs in complex procurements. This interplay also relates to three sensegiving supplier roles ('confidence builders', 'competent collaborators', and 'problemsolvers'), with these evolving dynamically during implementation. These findings support a conceptual model of the apparent linkages between sensemaking, sensegiving and buyer firm absorptive capacity in complex procurements. Given these observations, the study is among the first to address sensemaking, sensegiving and absorptive capacity in complex procurement contexts. The findings have the potential to influence the actions of FLE managers when making decisions about the time and resources they invest in FLE sensemaking activities, noting that these ultimately affect the absorptive capacity of the buyer firm as a whole. 


\section{References}

Aarikka-Stenroos, L., and Jaakkola, E. (2012). Value co-creation in knowledge intensive business services: A dyadic perspective on the joint problem solving process. Industrial Marketing Management, 41(1), 15-26.

Abrahamsen, M. H., Henneberg, S. C., and Naudé, P. (2012). Using actors' perceptions of network roles and positions to understand network dynamics. Industrial Marketing Management, 41(2), 259-269.

Agnihotri, R., Vieira, V. A., Senra, K. B., and Gabler, C. B. (2016). Examining the impact of salesperson interpersonal mentalizing skills on performance: the role of attachment anxiety and subjective happiness. Journal of Personal Selling and Sales Management, $36(2), 174-189$.

Ahern, T., Leavy, B., and Byrne, P. J. (2014). Knowledge formation and learning in the management of projects: A problem solving perspective. International Journal of Project Management, 32(8), 1423-1431.

Ali, M., Seny Kan, K. A., and Sarstedt, M. (2016). Direct and configurational paths of absorptive capacity and organizational innovation to successful organizational performance. Journal of Business Research, 69(11), 5317-5323.

Andersen, P. H., Kragh, H., and Lettl, C. (2013). Spanning organizational boundaries to manage creative processes: The case of the LEGO Group. Industrial Marketing Management, 42(1), 125-134.

Atkinson, P., and Hammersley, M. (1995). Ethnography (2nd ed.). London, UK: Routledge.

Balasubramanian, S., Bhattacharya, S., and Krishnan, V. V. (2015). Pricing information goods: A Strategic analysis of the selling and on-demand pricing mechanisms. Marketing Science, 34(2), 218-234.

Ballantyne, D., Frow, P., Varey, R. J., and Payne, A. (2011). Value propositions as communication practice: Taking a wider view. Industrial Marketing Management, $40(2), 202-210$.

Bechky, B. A. (2006). Gaffers, gofers, and grips: Role-based coordination in temporary organizations. Organization Science, 17(1), 3-21.

Biddle, B. J. (1986). Recent developments in role-theory. Annual Review of Sociology, 12, 67-92.

Biggemann, S., Kowalkowski, C., Maley, J., and Brege, S. (2013). Development and implementation of customer solutions: A study of process dynamics and market shaping. Industrial Marketing Management, 42(7), 1083-1092.

Brach, S., Walsh, G., Hennig-Thurau, T., and Groth, M. (2015). A dyadic model of customer orientation: Mediation and moderation effects. British Journal of Management, 26(2), 292-309.

Brady, T., Davies, A., and Gann, D. M. (2005). Creating value by delivering integrated solutions. International Journal of Project Management, 23(5), 360-365.

Brown, A. D., and Jones, M. R. (1998). Doomed to failure: Narratives of inevitability and conspiracy in a failed IS project. Organization Studies, 19(1), 73-88.

Burke, C. M., and Morley, M. J. (2016). On temporary organizations: A review, synthesis and research agenda. Human Relations, 69(6), 1235-1258.

Cadwallader, S., Jarvis, C. B., Bitner, M. J., and Ostrom, A. L. (2010). Frontline employee motivation to participate in service innovation implementation. Journal of the Academy of Marketing Science, 38(2), 219-239.

Cantù, C., Corsaro, D., and Snehota, I. (2012). Roles of actors in combining resources into 
complex solutions. Journal of Business Research, 65(2), 139-150.

Cayla, J., and Arnould, E. (2013). Ethnographic stories for market learning. Journal of Marketing, 77(Juiy), 1-16.

Certa, A., Enea, M., Galante, G., and Manuela La Fata, C. (2009). Multi-objective human resources allocation in $\mathrm{R} \& \mathrm{D}$ projects planning. International Journal of Production Research, 47(13), 3503-3523.

Chen, C. C., Law, C., and Yang, S. C. (2009). Managing ERP implementation failure: A project management perspective. IEEE Transactions on Engineering Management, 56(1), 157-170.

Choi, H., Kim, S., and Lee, J. (2010). Role of network structure and network effects in diffusion of innovations. Industrial Marketing Management, 39(1), 170-177.

Coelho, F., and Augusto, M. (2010). Job characteristics and the creativity of frontline service employees. Journal of Service Research, 13(4), 426-438.

Cohen, W. M., and Levinthal, D. A. (1989). Innovation and learning: The two faces of R\&D. The Economic Journal, 99(397), 569-596.

Cohen, W. M., and Levinthal, D. A. (1990). Absorptive capacity: A new perspective on learning and innovation. Administrative Science Quarterly, 35, 128-152.

Colville, I., and Pye, A. (2010). A sensemaking perspective on network pictures. Industrial Marketing Management, 39(3), 372-380.

Corsaro, D., Ramos, C., Henneberg, S. C., and Naudé, P. (2011). Actor network pictures and networking activities in business networks: An experimental study. Industrial Marketing Management, 40(6), 919-932.

Coviello, N. E., and Joseph, R. M. (2012). Creating major innovations with customers: Insights from small and young technology firms. Journal of Marketing, 76(6), 87-104.

Dubois, A., and Gadde, L.-E. (2014). "Systematic combining"-A decade later. Journal of Business Research, 67(6), 1277-1284.

Dubois, A., and Gadde, L. E. (2002). Systematic combining: An abductive approach to case research. Journal of Business Research, 55(7), 553-560.

Dyer, J. H., and Singh, H. (1998). The relational view: Cooperative strategy and sources of interorganizational competitive advantage. Academy of Management Review, 23(4), $660-679$.

Ellis, N., and Hopkinson, G. (2010). The construction of managerial knowledge in business networks: Managers' theories about communication. Industrial Marketing Management, 39(3), 413-424.

Fetterman, D. M. (2010). Ethnography: Step-by-Step. Applied Social Research Methods Series (3rd ed.). Thousand Oaks, CA: Sage Publications Inc.

Fiss, P. C., and Zajac, E. J. (2006). The symbolic management of strategic change: Sensegiving via framing and decoupling. Academy of Management Journal, 49(6), $1173-1193$.

Flowers, S. (2004). Contingent Capabilities and the procurement of complex product systems. International Journal of Innovation Management, 8(1), 1-20.

Flowers, S. (2007). Organizational capabilities and technology acquisition: why firms know less than they buy. Industrial and Corporate Change, 16(3), 317-346.

Gadde, L.-E., Huemer, L., and Håkansson, H. (2003). Strategizing in industrial networks. Industrial Marketing Management, 32(5), 357.

Geiger, S., and Finch, J. (2010). Networks of mind and networks of organizations: The map metaphor in business network research. Industrial Marketing Management, 39(3), 381389.

Gioia, D. A., and Chittipeddi, K. (1991). Sensemaking and Sensegiving in strategic change initiation. Strategic Management Journal, 12(6), 433-448. 
Goolsby, J. R. (1992). A theory of role stress in boundary spanning positions of marketing organizations. Journal of the Academy of Marketing Science, 20(2), 155-164.

Grabher, G. (2004). Temporary architectures of learning: Knowledge governance in project ecologies. Organization Studies, 25(9), 1491-1514.

Grayson, K. (2007). Friendship versus business in marketing relationships. Journal of Marketing, 71(October), 121-139.

Grönroos, C. (2008). Service logic revisited: who creates value? And who co-creates? European Business Review, 20(4), 298-314.

Grönroos, C. (2011). Value co-creation in service logic: A critical analysis. Marketing Theory, 11(3), 279-301.

Grönroos, C., and Voima, P. (2013). Critical service logic: making sense of value creation and co-creation. Journal of the Academy of Marketing Science, 41(2), 133-150.

Haas, M. R. (2006). Acquiring and applying knowledge in transnational teams: The roles of cosmopolitans and locals. Organization Science, 17(3), 367-384.

Haas, M. R., Criscuolo, P., and George, G. (2015). Which problems to solve? Online knowledge sharing and attention allocation in organizations. Academy of Management Journal, 58(3), 680-711.

Henneberg, S. C., Naudé, P., and Mouzas, S. (2010). Sense-making and management in business networks - some observations, considerations, and a research agenda. Industrial Marketing Management, 39(3), 355-360.

Hill, R. C., and Levenhagen, M. (1995). Metaphors and mental models: Sensemaking and sensegiving in innovative and entrepreneurial activities. Journal of Management, 21(6), 1057-1074.

Hilton, T., Hughes, T., and Chalcraft, D. (2012). Service co-creation and value realisation. Journal of Marketing Management, 28(13-14), 1504-1519.

Ho, H., and Ganesan, S. (2013). Does knowledge base compatibility help or hurt knowledge sharing between suppliers in competition? The role of customer participation. Journal of Marketing, 77(6), 91-107.

Hoegl, M., and Gemuenden, H. G. (2001). Teamwork quality and the success of innovative projects: A theoretical concept and empirical evidence. Organization Science, 12(4), 435-449.

Holmen, E., Aune, T. B., and Pedersen, A.-C. (2013). Network pictures for managing key supplier relationships. Industrial Marketing Management, 42(2), 139-151.

Homburg, C., Wieseke, J., and Bornemann, T. (2009). Implementing the marketing concept at the employee-customer interface: the role of customer need knowledge. Journal of Marketing, 73(July), 64-81.

Hong, J. F. L., Snell, R. S., and Mak, C. (2016). Knowledge assimilation at foreign subsidiaries of Japanese MNCs through political sensegiving and sensemaking. Organization Studies, 37(9), 1297-1321.

Hung, K. (2014). Why Celebrity Sells: A dual entertainment path model of brand endorsement. Journal of Advertising, 43(2), 155-166.

James, L. R., Demaree, R. G., and Wolf, G. (1984). Estimating within-group interrater reliability with and without response bias. Journal of Applied Psychology, 69(1), 85-98.

Jayachandran, S., Sharma, S., Kaufman, P., and Raman, P. (2005). The role of relational information processes and technology use in customer relationship management. Journal of Marketing, 69(October), 177-192.

Kalou, Z., and Sadler-Smith, E. (2015). Using ethnography of communication in organizational research. Organizational Research Methods, 18(4), 629-655.

Kano, L., and Verbeke, A. (2015). The three faces of bounded reliability: Alfred Chandler and the micro-foundations of management theory. California Management Review, 
$58(1), 97-123$.

Korschun, D. (2015). Boundary-spanning employees and relationships with external stakeholders: A social identity approach. Academy of Management Review, 40(4), 611629.

Leek, S., and Mason, K. (2010). The utilisation of network pictures to examine a company's employees' perceptions of a supplier relationship. Industrial Marketing Management, 39(3), 400-412.

Levin, E., Thaichon, P., and Quach, T. N. (2016). The impact of creative competence and project management on longevity of the client-advertising agency relationship. Journal of Business and Industrial Marketing, 31(2), 274-286.

Lewin, A. Y., Massini, S., and Peeters, C. (2011). Microfoundations of internal and external absorptive capacity routines. Organization Science, 22(1), 81-98.

Li, S., and Scullion, H. (2010). Developing the local competence of expatriate managers for emerging markets: A knowledge-based approach. Journal of World Business, 45(2), 190-196.

Liao, Y., and Marsillac, E. (2015). External knowledge acquisition and innovation: the role of supply chain network-oriented flexibility and organisational awareness. International Journal of Production Research, 53(18), 5437-5455.

Lincoln, Y., and Guba, E. G. (1985). Naturalistic Enquiry. Beverly Hills, CA: Sage Publications.

Lindner, F., and Wald, A. (2011). Success factors of knowledge management in temporary organizations. International Journal of Project Management, 29(7), 877-888.

Liu, Y., Huang, Y., Luo, Y., and Zhao, Y. (2012). How does justice matter in achieving buyer-supplier relationship performance? Journal of Operations Management, 30(5), $355-367$.

Lundgren-Henriksson, E. L., and Kock, S. (2016). Coopetition in a headwind - The interplay of sensemaking, sensegiving, and middle managerial emotional response in coopetitive strategic change development. Industrial Marketing Management, 58, 20-34.

Lysonski, S. J., and Johnson, E. M. (1983). The sales manager as a boundary spanner: A role theory analysis. Journal of Personal Selling and Sales Management, 3(2), 8-14.

Maitlis, S., and Lawrence, T. B. (2007). Triggers and enablers of sensegiving in organizations. Academy of Management Journal, 50(1), 57-84.

Mäläskä, M., Saraniemi, S., and Tähtinen, J. (2011). Network actors' participation in B2B SME branding. Industrial Marketing Management, 40(7), 1144-1152.

Martinsuo, M., and Ahola, T. (2010). Supplier integration in complex delivery projects: Comparison between different buyer-supplier relationships. International Journal of Project Management, 28(2), 107-116.

Mattsson, L. G., Corsaro, D., and Ramos, C. (2015). Sense-making in business markets - the interplay between cognition, action and outcomes. Industrial Marketing Management, 48, 4-11.

McGaffey, T. N., and Christy, R. (1975). Information processing capability as a predictor of entrepreneurial effectiveness. Academy of Management Journal, 18(4), 857-864.

Miles, M. B., and Huberman, A. M. (1994). Qualitative Data Analysis: An Expanded Sourcebook (2nd ed.). Thousand Oaks, CA: Sage Publications Inc.

Mills, P. K., and Morris, J. H. (1986). Clients as "partial" employees of service organizations: Role development in client participation. Academy of Management Review, 11(4), 726735.

Monin, P., Noorderhaven, N., Vaara, E., and Kroon, D. (2013). Giving sense to and making sense of justice in postmerger integration. Academy of Management Journal, 56(1), 256-284. 
Mouzas, S., and Henneberg, S. C. (2015). Inter-cognitive representations in business networks. Industrial Marketing Management, 48, 61-67.

Murovec, N., and Prodan, I. (2009). Absorptive capacity, its determinants, and influence on innovation output: Cross-cultural validation of the structural model. Technovation, 29(12), 859-872.

Nagati, H., and Rebolledo, C. (2012). The role of relative absorptive capacity in improving suppliers' operational performance. International Journal of Operations and Production Management, 32(5), 611-630.

Nätti, S., Hurmelinna-Laukkanen, P., and J. Johnston, W. (2014). Absorptive capacity and network orchestration in innovation communities: Promoting service innovation. Journal of Business and Industrial Marketing, 29(2), 173-184.

Neely, P. A. (2014). Solution business models based on functional modularity-the case of complex capital goods. Journal of Service Management, 25(5), 654-676.

Nonis, S. A., Sager, J. K., and Kumar, K. (1996). Salespeople's use of upward influence tactics (UITs) in coping with role stress. Journal of the Academy of Marketing Science, 24(1), 44-56.

Peters, L. D., Pressey, A. D., and Johnston, W. J. (2016). Contingent factors affecting network learning. Journal of Business Research, 69(7), 2507-2515.

Petkova, A. P., Rindova, V. P., and Gupta, A. K. (2013). No news is bad news: Sensegiving activities, media attention, and venture capital funding of new technology organizations. Organization Science, 24(3), 865-888.

Pressey, A. D., Gilchrist, A. J. P., and Lenney, P. (2014). Sales and marketing resistance to Key Account Management implementation: An ethnographic investigation. Industrial Marketing Management, 43(7), 1157-1171.

Preston, D. S., Chen, D. Q., Swink, M., and Meade, L. (2016). Generating Supplier benefits through buyer-enabled knowledge enrichment: A social capital perspective. Decision Sciences, 48(2), 248-287.

Prior, D. D. (2013). Supplier representative activities and customer perceived value in complex industrial solutions. Industrial Marketing Management, 42(8), 1192-1201.

Prior, D. D. (2016). Boundary spanning and customer service styles in business solutions implementation. Industrial Marketing Management, 56, 120-129.

Reich, B. (2007). Managing knowledge and learning in IT projects: A conceptual framework and guidelines for practice. Project Management Journal, 38(2), 5-17.

Reiman, F., Shen, P., and Kaufmann, L. (2016). Effectiveness of power use in buyer-supplier negotiations: The moderating role of negotiator agreeableness. International Journal of Physical Distribution and Logistics Management, 46(10), 932-952.

Robertson, M., Scarbrough, H., Swan, J., and Scarbrough, H. (2003). Knowledge creation in professional service firms: Institutional effects. Organization Studies, 24(6), 831-857.

Roseira, C., Brito, C., and Ford, D. (2013). Network pictures and supplier management: An empirical study. Industrial Marketing Management, 42(2), 234-247.

Santos-Vijande, M. L., López-Sánchez, J. Á., and Rudd, J. (2016). Frontline employees' collaboration in industrial service innovation: routes of co-creation's effects on new service performance. Journal of the Academy of Marketing Science, 44(3), 350-375.

Santos, J. B., and Spring, M. (2015). Are knowledge intensive business services really coproduced? Overcoming lack of customer participation in KIBS. Industrial Marketing Management, 50, 85-96.

Shepherd, D. A., Patzelt, H., and Wolfe, M. (2011). Moving forward from project failure: Negative emotions, affective commitment, and learning from the experience. Academy of Management Journal, 54(6), 1229-1259.

Shore, B. (2008). Systematic biases and culture in project failures. Project Management 
Journal, 39(4), 5-16.

Siehl, C., Bowen, D. E., and Pearson, C. M. (1992). Service encounters as rites of integration: An information processing model. Organization Science, 3(4), 537-556.

Söderlund, J., Hobbs, B., and Ahola, T. (2014). Project-based and temporary organizing: Reconnecting and rediscovering. International Journal of Project Management, 32(7), $1085-1090$.

Spence, M. T., and Brucks, M. (1997). The moderating effects of problem characteristics on experts' and novices' judgments. Journal of Marketing Research, 34(2), 233-247.

Squire, B., Cousins, P. D., and Brown, S. (2009). Cooperation and knowledge transfer within buyer-supplier relationships: The moderating properties of trust, relationship duration and supplier performance. British Journal of Management, 20(4), 461-477.

Stolze, H. J., Murfield, M. L. U., and Esper, T. L. (2015). The role of social mechanisms in demand and supply integration: An individual network perspective. Journal of Business Logistics, 36(1), 49-68.

Tangpong, C., Hung, K. T., and Ro, Y. K. (2010). The interaction effect of relational norms and agent cooperativeness on opportunism in buyer-supplier relationships. Journal of Operations Management, 28(5), 398-414.

Tidström, A., and Rajala, A. (2016). Coopetition strategy as interrelated praxis and practices on multiple levels. Industrial Marketing Management, 58, 35-44.

Tinsley, H. E., and Weiss, D. J. (1975). Interrater reliability and agreement of subjective judgments. Journal of Counseling Psychology, 22(4), 358-376.

Todorova, G., and Durisin, B. (2007). Absorptive capacity: Valuing a reconceptualization. Academy of Management Review, 32(3), 774-786.

Töllner, A., Blut, M., and Holzmüller, H. H. (2011). Customer solutions in the capital goods industry: Examining the impact of the buying center. Industrial Marketing Management, 40(5), 712-722.

Tourish, D., and Robson, P. (2006). Sensemaking and the distortion of critical upward communication in organizations. Journal of Management Studies, 43(4), 711-730.

Tuli, K. R., Kohli, A. K., and Bharadwaj, S. G. (2007). Rethinking Customer Solutions: From Product Bundles to Relational Processes. Journal of Marketing, 71(3), 1-17.

Turner, J. R., and Müller, R. (2003). On the nature of the project as a temporary organization. International Journal of Project Management, 21(1), 1-8.

van Maanen, J., Sørensen, J. B., and Mitchell, T. R. (2007). The interplay between theory and method. Academy of Management Review, 32(4), 1145-1154.

Vanpoucke, E., Vereecke, A., and Boyer, K. K. (2014). Triggers and patterns of integration initiatives in successful buyer-supplier relationships. Journal of Operations Management, 32(1-2), 15-33.

Vargo, S. L., Maglio, P. P., and Akaka, M. A. (2008). On value and value co-creation: A service systems and service logic perspective. European Management Journal, 26(3), $145-152$.

Verbeke, A., and Greidanus, N. S. (2009). The end of the opportunism vs trust debate : Bounded reliability as a new envelope concept in research on MNE governance. Journal of International Business Studies, 40(9), 1471-1495.

Vlaar, P. W. L., Van den Bosch, F. A. J., and Volberda, H. W. (2006). Coping with problems of understanding in interorganizational relationships: Using Formalization as a means to make sense. Organization Studies, 27(11), 1617-1638.

Waller, M. J. (1999). The timing of adaptive group responses to nonroutine events. Academy of Management Journal, 42(2), 127-137.

Wang, G., Wang, X., Long, Y., Hou, W. C., and Ching, L. A. (2015). Buyer loyalty in business markets: Can the firm and salesperson get what they truly desire? Journal of 
Business-to-Business Marketing, 22(3), 197-210.

Weick, K. E. (1995). Sensemaking in Organizations. Thousand Oaks, CA: Sage Publications Inc.

Weick, K. E., Sutcliffe, K. M., and Obstfeld, D. (2005). Organizing and the process of sensemaking. Organization Science, 16(4), 409-421.

Wieseke, J., Ahearne, M., Lam, S. K., and Dick, R. Van. (2009). The role of leaders in internal marketing. Journal of Marketing, 73(2), 123-145.

Yang, Z. (Ben), and Babich, V. (2014). Does a procurement service provider generate value for the buyer through information about supply risks? Management Science, 61(5), 979998.

Yin, R. K. (2009). Case Study Research - Design and Methods (4th ed.). Thousand Oaks, California, USA: Sage Inc.

Zahara, S. A., and George, G. (2002). Absorptive capacity: A review, reconceptualization, and extension. Academy of Management Review, 27(2), 185-203.

Zaheer, A., Hernandez, E., and Banerjee, S. (2010). Prior alliances with targets and acquisition performance in knowledge-intensive industries. Organization Science, 21(5), 1072-1091. 


\section{Appendix}

\section{Discussion Guide}

1. Could you describe your background, industry expertise and current role in your company? [Respondents were probed for evidence that they are/have been part of and/or have significant experience of complex procurements].

2. In your opinion, what kind of offerings represent complex procurements to you? [Respondents were probed to describe and clarify what kind of offerings represented complex procurements to them, and how they differed from standard and less complex procurements].

3. What factors do you evaluate when considering complex procurements? Are some factors more important than others? [Respondents were probed to elaborate and clarify their decision process and criteria related to complex procurements].

4. How do you evaluate alternative suppliers? [Respondents were probed for the criteria that they used to evaluate different supplier firms that delivered offerings that were considered complex procurements].

5. How do you conduct complex procurements? [Respondents were probed for their typical complex procurement practices].

6. How well do suppliers usually succeed in deploying and implementing the solution? What does this require from the customer? [Respondents were probed for their role and typical challenges faced during the implementation of complex procurements].

7. What kind of challenges do you usually face during the early stages of complex procurements? [Respondents were probed for the nature and characteristics of the challenges they faced during early stages (i.e. pre-sales) of complex procurements and how those challenges influenced subsequent engagement decisions].

8. How well do suppliers help you to operate and maintain the solution after implementation? [Respondents were probed for their role and typical challenges faced after complex procurements].

9. To recap, in your opinion, what are the key challenges in complex procurements? [Respondents were probed to elaborate and clarify the most important issues that had emerged during the interview].

[In addition, where appropriate, respondents where probed for concrete examples, as well as clarification of specific decision making processes and engagement practices for each key episode or interaction they described during the interview]. 


\section{FIGURES}

Figure 1 Supplier FLE Sensegiving Roles

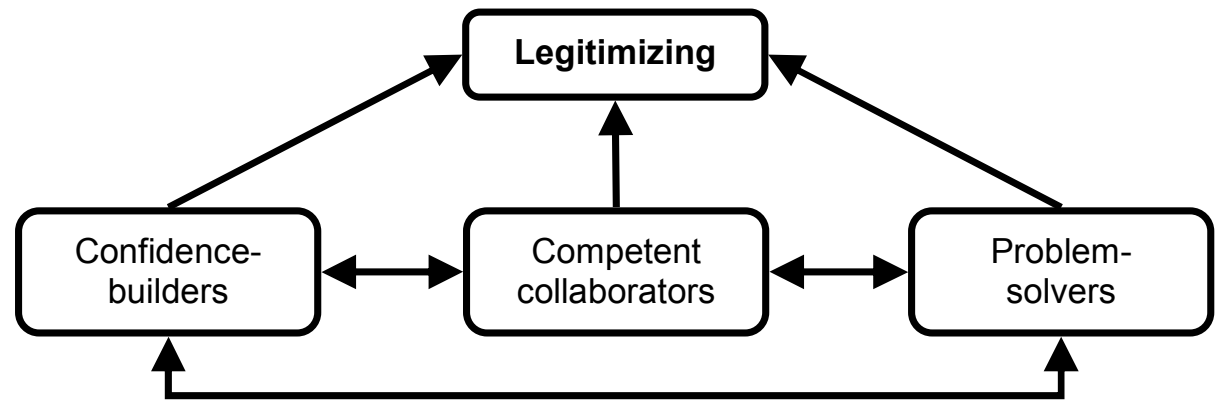


Figure 2 A Conceptual Model of Sensemaking, Sensegiving and Absorptive Capacity in Complex Procurements

\section{Sensemaking processes}

Absorptive capacity processes

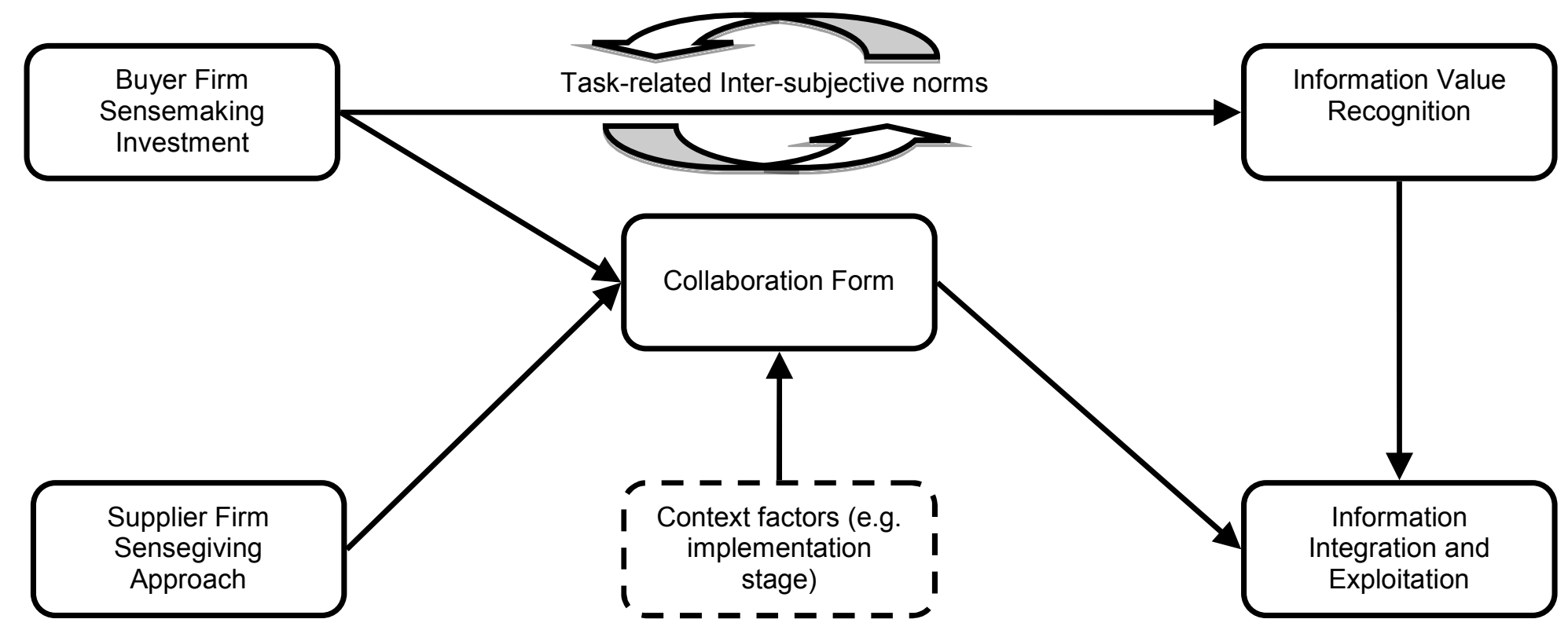




\section{TABLES}

Table 1 Interview Respondents

\begin{tabular}{|l|l|c|}
\hline Firm & Titles of informants & Industry experience \\
\hline 1 & Design Manager & 35 years \\
\hline 2 & Process Manager & 34 years \\
\hline 3 & Project Delivery Manager & 20 years \\
\hline 4 & Principal Process Engineer & 20 years \\
\hline 5 & Project Engineer & years \\
\hline 6 & Process Engineer & 15 years \\
\hline 7 & Procurement Manager & 40 years \\
\hline 8 & Project Manager & 10 years \\
\hline $9 \mathrm{a}^{\wedge}$ & CEO & 28 years \\
\hline $9 \mathrm{~b}$ & GM, Technology & 22 years \\
\hline $10 \mathrm{a}$ & General Manager & 25 years \\
\hline $10 \mathrm{~b}$ & Engineering Project Manager & 28 years \\
\hline 11 & Project Supervisor & 7 years \\
\hline 12 & Chief Metallurgist & 20 years \\
\hline 13 & Chief Metal Engineer & 15 years \\
\hline 14 & Manager, Process Engineering & 15 years \\
\hline 15 & Process and Metallurgical Engineer & 9 years \\
\hline 16 & Senior Process Metallurgist & 13 years \\
\hline 17 & Senior Process Engineer & 13 years \\
\hline 18 & Senior Process Metallurgist & 13 years \\
\hline 19 & Metallurgist Engineer & 11 years \\
\hline 20 & Civil Engineer Metallurgist & 26 years \\
\hline
\end{tabular}

${ }^{\wedge} \mathrm{NB}$. Where more than one respondent participated in the study, we use the same firm number, and a lower case letter to denote separate individuals. 
Table 2 Sensemaking and Collaboration Coding Attributes

\begin{tabular}{|c|c|c|c|}
\hline Theme & Definition & Sub-Themes & Supporting Literature \\
\hline \multirow{3}{*}{$\begin{array}{l}\text { Sensemaking } \\
\text { activities (as } \\
\text { specific } \\
\text { investments) }\end{array}$} & \multirow{3}{*}{$\begin{array}{l}\text { Buyer firm FLE } \\
\text { allocations of time, effort } \\
\text { and resources towards } \\
\text { interpreting supplier } \\
\text { information }\end{array}$} & $\begin{array}{l}\text { - Information } \\
\text { appraisal }\end{array}$ & $\begin{array}{c}\text { Balasubramanian, Bhattacharya, and } \\
\text { Krishnan (2015), Yang and Babich } \\
\text { (2014) }\end{array}$ \\
\hline & & $\begin{array}{l}\text { Information/ } \\
\text { knowledge } \\
\text { Processing }\end{array}$ & $\begin{array}{c}\text { Hong et al. (2016), Jayachandran, } \\
\text { Sharma, Kaufman, and Raman (2005), } \\
\text { McGaffey and Christy (1975), Siehl, } \\
\text { Bowen, and Pearson (1992) }\end{array}$ \\
\hline & & $\begin{array}{l}\text { - } \\
\text { allocation }\end{array}$ & $\begin{array}{c}\text { Cantù et al. (2012), Certa, Enea, } \\
\text { Galante, and Manuela La Fata (2009), } \\
\text { Haas, Criscuolo, and George (2015), } \\
\text { Prior (2013) }\end{array}$ \\
\hline \multirow[t]{3}{*}{$\begin{array}{l}\text { Sensegiving } \\
\text { activities (as } \\
\text { supplier } \\
\text { collaboration) }\end{array}$} & \multirow[t]{3}{*}{$\begin{array}{l}\text { Supplier firm FLE } \\
\text { allocations of time, effort } \\
\text { and resources towards } \\
\text { communicating task- } \\
\text { related information }\end{array}$} & $\begin{array}{l}\text { Influencing } \\
\text { through } \\
\text { storytelling, } \\
\text { metaphors and } \\
\text { narrative } \\
\end{array}$ & $\begin{array}{c}\text { Fiss and Zajac (2006), Gioia and } \\
\text { Chittipeddi (1991), Hill and } \\
\text { Levenhagen (1995), Monin et al. (2013) }\end{array}$ \\
\hline & & $\begin{array}{l}\text { Knowledge } \\
\text { bearing }\end{array}$ & Li and Scullion (2010) \\
\hline & & $\begin{array}{l}\text { - } \begin{array}{l}\text { Resource } \\
\text { allocation }\end{array} \\
\end{array}$ & $\begin{array}{c}\text { Certa et al. (2009), Haas et al. (2015), } \\
\text { Prior (2013) }\end{array}$ \\
\hline
\end{tabular}


Table 3 A Taxonomy of Supplier Collaboration vs. Buyer Firm Sensemaking Investment Approach

\begin{tabular}{|c|c|c|c|}
\hline \multirow{2}{*}{ 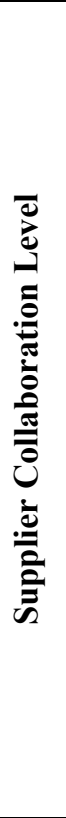 } & 昰 & $\begin{array}{l}\text { Type I } \\
\text { - Assign low priority to internal sensemaking processes } \\
\text { - Heavy reliance on external suppliers as sense-givers } \\
\text { - Propensity for pull-based information exchange } \\
\text { Indicative Quotation: "To be honest, one of the challenges is that we are } \\
\text { working with very little information, and a lot of it is dependent on the } \\
\text { expertise of people that can apply their knowledge to other products or } \\
\text { operations. So, the challenge is actually that we can't formulate a design for a } \\
\text { plant based on very limited information and that's where companies like [a } \\
\text { supplier] can actually add a lot of value." (14). }\end{array}$ & $\begin{array}{l}\text { Type II } \\
\text { - Confident in their own ability, extensive investment in sensemaking } \\
\text { - Heavy reliance on external suppliers as sense-givers, particularly for } \\
\text { specific topic areas } \\
\text { - Propensity for pull-based information exchange } \\
\text { Indicative Quotation: "We always need to call for technical support... } \\
\text { [Training] is the most common practice here. People can learn very fast. } \\
\text { There are many things that people don't know. But using the manuals, using } \\
\text { the experience from other people, we can operate one [piece of] equipment. At } \\
\text { least if it is not too difficult to do. But for example, for a pump, for a filter, it } \\
\text { needs training for at least one person." (15). }\end{array}$ \\
\hline & ؛ & $\begin{array}{l}\text { Type III } \\
\text { - Assign low priority to internal sensemaking processes } \\
\text { - Suppliers as 'enemies' that can fulfil certain needs } \\
\text { - Propensity for push-based information exchange } \\
\text { Indicative Quotation: "We don't want to hear suppliers' marketing } \\
\text { propaganda as most of the time they tell us what they think we need - not } \\
\text { necessarily what we want. The supplier is required to listen to us and offer } \\
\text { exactly what we want. We don't have to suit to what they think we need." (7). }\end{array}$ & $\begin{array}{l}\text { Type IV } \\
\text { - Confident in their own ability, extensive investment in sensemaking } \\
\text { - Suppliers as 'enemies' that can fulfil certain needs } \\
\text { - Propensity for push-based information exchange } \\
\text { Indicative Quotation: "We don't believe there are any genuine solution } \\
\text { suppliers available in the market - only packages. If we need a hole we always } \\
\text { get a drill and we have to turn that into a hole. These packages require a lot of } \\
\text { work further from us to be able to bring it to a stage it actually appears like a } \\
\text { solution to our needs." (8). }\end{array}$ \\
\hline & & Low & $\begin{array}{lll}2.20 & \text { High }\end{array}$ \\
\hline
\end{tabular}


Table 4 Supplier Sensegiving Roles

\begin{tabular}{|c|c|c|c|c|}
\hline Role & Definition & Example Behaviors & Outcome & Supportive Literature \\
\hline \multirow[t]{2}{*}{$\begin{array}{l}\text { Confidence- } \\
\text { builders }\end{array}$} & $\begin{array}{l}\text { The explicit } \\
\text { endorsement of } \\
\text { buyer firm FLE } \\
\text { actions }\end{array}$ & $\begin{array}{ll}\text { - } & \text { Sending an email with } \\
\text { supportive information } \\
\text { - } & \text { Providing written } \\
\text { references } \\
\text { - } \\
\text { Offering a supportive } \\
\text { anecdote in a meeting }\end{array}$ & $\begin{array}{l}\text { Lower } \\
\text { perceived } \\
\text { risk }\end{array}$ & $\begin{array}{l}\text { Hung (2014), Liu et al. } \\
\text { (2012) }\end{array}$ \\
\hline & \multicolumn{4}{|c|}{$\begin{array}{l}\text { Indicative quotation: "We use commercializing experts to make value propositions that show how we } \\
\text { differentiate based on speed, scope, budget, and flexibility. And then show how this compares to other } \\
\text { options... our goal is risk mitigation, and feasibility studies help us to convince the customer's } \\
\text { stakeholders". (15). }\end{array}$} \\
\hline \multirow[t]{2}{*}{$\begin{array}{l}\text { Competent } \\
\text { collaborators }\end{array}$} & $\begin{array}{l}\text { Simplifying } \\
\text { information } \\
\text { about context, } \\
\text { the nature of } \\
\text { problems and/ } \\
\text { or engaging } \\
\text { directly in task } \\
\text { completion }\end{array}$ & $\begin{array}{ll}\text { - } & \text { Summarizing complex } \\
\text { information and } \\
\text { presenting it in an email } \\
\text { or report } \\
\text { Recommending specific } \\
\text { actions that demonstrate } \\
\text { in-depth task knowledge } \\
\text { Engaging in sophisticated } \\
\text { conversations with key } \\
\text { stakeholders }\end{array}$ & $\begin{array}{ll}\text { - } & \text { Lower } \\
\text { perceived } \\
\text { complexity } \\
\text { - } & \text { Lower } \\
\text { perceived } \\
\text { uncertainty }\end{array}$ & $\begin{array}{l}\text { Gioia and Chittipeddi } \\
\text { (1991), Lundgren- } \\
\text { Henriksson and Kock, } \\
\text { (2016), Petkova, } \\
\text { Rindova, and Gupta } \\
\text { (2013) }\end{array}$ \\
\hline & \multicolumn{4}{|c|}{$\begin{array}{l}\text { Indicative quotation: "We can proactively design and prepare the implementation stages, and this } \\
\text { allows us to design different service bundles including analyses of usability, maintenance, and third party } \\
\text { vendor components. If the customers buys from us, he will get a perfect list of all the nuts and bolts that he } \\
\text { will need during the implementation". (17). }\end{array}$} \\
\hline \multirow[t]{2}{*}{$\begin{array}{l}\text { Problem- } \\
\text { solvers }\end{array}$} & $\begin{array}{l}\text { Identifying, } \\
\text { describing and/ } \\
\text { or enacting } \\
\text { courses of } \\
\text { action that } \\
\text { address } \\
\text { implementation } \\
\text { problems }\end{array}$ & 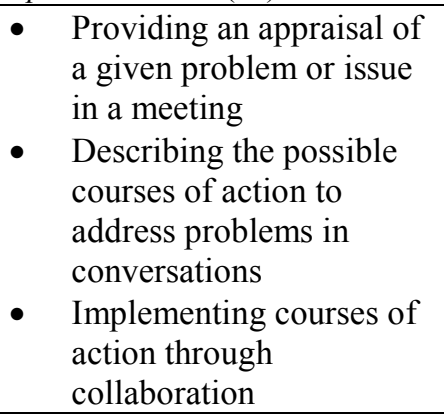 & 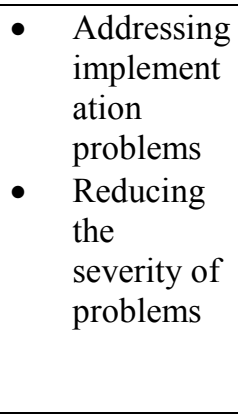 & $\begin{array}{l}\text { Aarikka-Stenroos and } \\
\text { Jaakkola (2012), } \\
\text { Ahern, Leavy, and } \\
\text { Byrne (2014), Spence } \\
\text { and Brucks (1997) }\end{array}$ \\
\hline & \multicolumn{4}{|c|}{$\begin{array}{l}\text { Indicative quotation: "They have always answered my questions, they are always around us talking } \\
\text { about their new technologies, their new plants, and so on". (16). }\end{array}$} \\
\hline
\end{tabular}


Table 5 Supplier Sensegiving Roles during Implementation Stage

\begin{tabular}{|c|c|c|c|}
\hline Type & Pre-Sales & During Implementation & $\begin{array}{r}\text { Post-Implementation } \\
\end{array}$ \\
\hline I & $\begin{array}{l}\text { As confidence-builders: } \\
\text { - Signaling expertise and capabilities } \\
\text { - Developing formal project plans } \\
\text { "Well, with permanent assistance and contact ... we } \\
\text { always ask for guarantees, warranties, there are } \\
\text { penalties, too ... when we prepare the quotation, we } \\
\text { ask for warranties and we ask the same from } \\
\text { everyone." (19). }\end{array}$ & $\begin{array}{l}\text { As problem-solvers: } \\
\text { - Leading implementation and installation } \\
\text { - Coordinating processes and activities } \\
\text { "We don't have direct experience..., the owners } \\
\text { sometimes, they don't know how to manage the } \\
\text { schedules of the projects or how to integrate } \\
\text { different areas ... [or have] negotiation ability } \\
\text { skills." (18). }\end{array}$ & $\begin{array}{l}\text { As problem-solvers: } \\
\text { - Conducting maintenance and trouble-shooting } \\
\text { - Proposing solutions for evolving requirements } \\
\text { "From a technical point of view, [the supplier] is } \\
\text { very strong, the know-how and technical solution is } \\
\text { very good, but we don't see the [supplier's] people } \\
\text { working together with us at site. We don't see your } \\
\text { sales person asking at the site, what we need, what is } \\
\text { the next project, how can I help you." (20). }\end{array}$ \\
\hline II & $\begin{array}{l}\text { As competent collaborators: } \\
\text { - } \quad \text { Evaluating alternative product/service options } \\
\text { - Co-designing plans and product/ service } \\
\text { solutions } \\
\text { "We like to work with them [vendors] to make sure } \\
\text { we get something that's going to be best for the } \\
\text { project,... the important thing for us is to work } \\
\text { together on the design, make sure that we are happy } \\
\text { with it, we can take then integrate it into our designs } \\
\text { and make sure everything interfaces properly, and } \\
\text { then we have a solution." (3). }\end{array}$ & $\begin{array}{l}\text { As problem-solvers: } \\
\text { - Staying updated of operational conditions } \\
\text { - } \quad \text { Reacting swiftly to customer requests } \\
\text { "When we do some project or work, we need to ask } \\
\text { her and we need fast answer: "Okay, let me check!" } \\
\text { and after } 3 \text { am or } 3 \text { pm "okay, this will be good in an } \\
\text { hour”... When I do that, it is not a waste of time, but } \\
\text { it's a time that I invest into her ... if something } \\
\text { happens with the pump... a little problem, problems } \\
\text { or anything else, we need to know that the supplier is } \\
\text { worried about what happened." (15). }\end{array}$ & $\begin{array}{l}\text { As problem-solvers: } \\
\text { - Providing training and operational support } \\
\text { - Sharing information and specialist knowledge } \\
\text { "They [suppliers] can help us ... to find out what is } \\
\text { the best technological fit. And also give us } \\
\text { information that we need in order to move the } \\
\text { project forward ... what's technologically feasible ... } \\
\text { [but] at this stage ... we don't need to know details, } \\
\text { because we just try to understand what the basics } \\
\text { project is about." (12). }\end{array}$ \\
\hline III & $\begin{array}{l}\text { As competent collaborators: } \\
\text { - Proposing alternative product/ service } \\
\text { combinations } \\
\text { - Demonstrating integration skills } \\
\text { "What is important is that vendors are aware of the } \\
\text { fact that... all the components of the entire process } \\
\text { must be integrated ... It's how you bundle all } \\
\text { together." (18). }\end{array}$ & $\begin{array}{l}\text { As problem-solvers: } \\
\text { - Ensuring product/ service fit existing systems } \\
\text { "If it is small equipment, they are just supplying the } \\
\text { equipment and ... the company buying it is installing } \\
\text { that themselves ... [if] it is bigger project where } \\
\text { you're buying lump sum turnkey type, most of the } \\
\text { smaller equipment, filter, pumps, agitators, they just } \\
\text { supply equipment, which then the engineering group, } \\
\text { whether it is internal or external installs." }(9 a) \text {. }\end{array}$ & $\begin{array}{l}\text { As problem-solvers: } \\
\text { - Conducting maintenance and trouble-shooting } \\
\text { - Reacting swiftly to customer requests } \\
\text { "It's the support after sales ... how do they support } \\
\text { the needs that we have and how fast do they respond } \\
\text { to our request." (18). } \\
\text { "The key thing is always giving insurance to the user } \\
\text { that these things [solutions] are continuously being } \\
\text { maintained and the users are always getting a better } \\
\text { solution." (14). }\end{array}$ \\
\hline
\end{tabular}




\begin{tabular}{|c|c|c|c|}
\hline IV & $\begin{array}{l}\text { As confidence-builders: } \\
\text { - Developing feasibility studies } \\
\text { - Providing customer references } \\
\text { - Conducting trials and test-runs } \\
\text { "We might have done three or four months of } \\
\text { technical due diligence to make sure it was the right } \\
\text { thing, it's not going to broke, we went to [other } \\
\text { country] to see one in operation." (2). }\end{array}$ & $\begin{array}{l}\text { As problem-solvers: } \\
\text { - Sharing information and specialist knowledge } \\
\text { - Keeping customers updated of process progress } \\
\text { "The best ones tells us what's happening. You know, } \\
\text { information is critical, quite often what will happen } \\
\text { is that you know the vendors will get the order, we } \\
\text { will have the proof of design and then there becomes } \\
\text { a big black hole and at the end of it something pops } \\
\text { out ... What we like to know is, what is happening, to } \\
\text { be involved." (3). }\end{array}$ & $\begin{array}{l}\text { As confidence-builders: } \\
\text { - Maintaining stakeholder communication } \\
\text { - Providing process guarantees and warranties } \\
\text { "I have been in number of situations where we have } \\
\text { purchased the equipment and as soon as it lands on } \\
\text { the site then they disappear and we never hear from } \\
\text { them again ... The most of the risks I usually see are } \\
\text { in aftersales, will they be there for us once we are } \\
\text { operating or are they just interested in the sale." (3). }\end{array}$ \\
\hline
\end{tabular}

